4. Зубцов, А.А. Разграничение норм о находке и тайном хищении чужого имущества: проблемы теории и практики// Уголовное право. - 2019 г. - №3. - 25-31 с.

5. Лазарев, А.М. Вопросы разграничения кражи и присвоения найденного чужого имущества// Вестник ВГАВТ. - 2017 г. - №53. - 227-233 с.

6. Филиппова, Л. А. Квалификация хищений / Л. А. Филиппова. - Текст: непосредственный // Молодой ученый. — 2019 г. — № 29 (267). — 121-123 с.

7. Хилюта, В.В. Кража и присвоение найденного: проблемы соотношения и выявления разграничительных признаков// Журнал российского права. - 2019 г. - №2. - 132-143 с.

\title{
Панова Е.И. \\ Правовая и процессуальная активность, как виды юридической активности
}

Российский государственный университет правосудия (Россия, Симферополь)

doi: $10.18411 / \mathrm{j}-07-2021-97$

\section{Аннотация}

В данном исследовании произведен анализ понятия правовая активность и процессуальная активность, обусловлена их роль в практической деятельности адвоката.

Ключевые слова: правовая активность, процессуальная активность, правовое государство, социально-правовая активность, юридическая деятельность, адвокат, представитель, защитник.

\section{Abstract}

This study analyzes the concepts of legal activity and procedural activity, and determines their role in the practice of a lawyer.

Keywords: legal activity, procedural activity, legal state, social and legal activity, legal activity, lawyer, representative, defender.

Введение. Основная цель судопроизводства - защита прав и свобод человека и гражданина (истца, ответчика, третьих лиц, потерпевшего, обвиняемого и т.д). Достижение этой цели возможно только при активных действиях граждан, чьи права затрагивает конкретный процесс. Актуальным является вопрос, насколько действующее законодательство предоставляет возможность физическим лица, участникам процессуальных правоотношений, отстаивать собственные права, определяя должное и возможное поведение.

Данные аспекты обусловили актуальность современного исследования роли правовой и процессуальной активности индивида в современном мире.

Цель исследования - изучить правовую и процессуальную активность, как виды юридической активности граждан в Российской Федерации.

Изложение основного материала. Исследуя научный материал по теме данного исследования, мы приходим к выводу, о том, что вопросы правовой активности подверглись достаточно тщательному анализу в литературе. Кроме того, правовая активность индивида может рассматриваться в узком и широком смысле. В широком смысле правовую активность индивида можно рассматривать как любую деятельность, которая так или иначе юридически обоснована, связана с участием в установленных нормами правах общественных отношений. В узком смысле правовая активность связана с юридическими действиями, связанными с конкретным лицом, конкретным субъектом права.

А.М. Лесникова данный термин понимает, как своего рода правовую деятельность, которая проявляется посредством реальных правовых действий, и которой присуща совместная оценка правоохранительными органами. В противном 
случае правовая активность остается лишь своеобразным юридическим поведением, выделяемым субъективным сторонами, и не может претендовать на независимый категориальный статус [1].

По мнению С.М. Воробьева, общественно-правовая активность - это «право, уважение права, признание высокого престижа деятельности юридических учреждений, поиск наиболее эффективных способов использования собственных прав индивида или выполнения его гражданских обязанностей, гражданский долг в области права» [2].

Как отмечает Ю.А. Маслак, социально-правовая активность «превосходит» обычные требования закона, более высокая степень сознания связана с большим интересом к позитивной деятельности по укреплению порядка демократии, законности и права [3].

Под правовой активностью, с точки зрения Т. В. Юлдашева, понимается степень зрелости, интенсивность, эффективность и модель юридического поведения, т.е. качественная особенность волеизъявлений людей в правовом поле.

Таким образом, общественно-правовая активность граждан, в отличие от других форм деятельности, представляет собой проявление их активности именно в сфере права.

Правовая деятельность имеет свои особенности-она формируется и реализуется в правовой сфере; ее реализация осуществляется на принципах свободы, добровольности и инициативы индивида; она направлена на изменение правоотношений; намерения субъекта правовой деятельности направлены на положительный юридический результат.

Статус граждан в судебных процессах представлен наличием более широкого круга элементов. В связи с тем, что деятельность-инициативная деятельность по своему усмотрению, статус ее субъектов не может быть обязательным, так как ее выполнение осуществляется не из собственных добровольных посылок субъекта, а под угрозой юридических санкций [4].

Следует отметить, что правовая деятельность-это прежде всего категория поведения, к определению которой юридическая наука применяет плюрализм подходов. Иными словами, правовые нормы устанавливают возможность выбора поведения: один из них предполагает активные действия, другой - таких действий не предусматривает.

Следовательно, правовая деятельность основана на непосредственной заинтересованности индивидов и организаций в осуществлении правовых норм, она является антиподом правового отчуждения и пассивности, неверия в силу и эффективность права [5].

Факторами, стимулирующими участников социальных отношений к социальной деятельности, являются социальные ценности. Соответственно, правовую деятельность следует рассматривать как вид социальной деятельности, направленный на реализацию правовых ценностей. Такой подход позволяет обнаружить положительный потенциал правовой деятельности, рассматривать ее с точки зрения независимой ценности как необходимое условие развития демократического правового государства [6].

Проводя анализ такого понятия, как процессуальная активность, в контексте данного исследования применительно в адвокатской деятельности отметим, что ключевым элементом осуществления адвокатом защиты в судопроизводстве, безусловно, является его правовая активность, точнее можно сказать процессуальноправовая активность. Адвокат является соотправителем правосудия, частью единого механизма, обеспечивающего надлежащее правоприменение. Он выполняет важную функцию, представляющую контраргументацию действиям противоположной стороны. Таким конфликтным взаимодействием элементов единого механизма обеспечивается достижение определенных законом целей. Ненадлежащее исполнение адвокатом 
определенных законом обязанностей по установлению фактических обстоятельств дела, критической оценке деятельности процессуальных органов и т.д., отсутствие реальных механизмов оценки эффективности и достаточности предпринимаемых адвокатом усилий зачастую способны привести лишь к формальному и не эффективному осуществлению функции защиты. Важность такого элемента осуществления правосудия по гражданским, уголовным, административным делам, в свою очередь, ставит под сомнение эффективность всего процессуального процесса и его соответствие общепризнанным принципам справедливого правосудия [7].

Представляется бесспорным, что адвокат должен проявлять требуемую для его профессии правовую, а именно процессуальную активность в отстаивании позиции своего подзащитного. Для этого адвокат обязан, в первую очередь, устанавливать обстоятельства дела, выявлять все благоприятные для своего доверителя обстоятельства и использовать их в процессе защиты. Именно такая процессуальная активность адвоката может быть охарактеризована как квалифицированная юридическая помощь.

В то же время практика дисциплинарных разбирательств свидетельствует о затруднительности привлечения адвокатов к ответственности в случае их пассивного поведения. Дисциплинарные органы адвокатских палат, осуществляющие надзор за выполнением адвокатами требований законодательства об адвокатской деятельности и адвокатуре, лишены эффективного инструментария по оценке качества юридической помощи. На данном этапе отсутствуют современные научные положения и рекомендации, которые бы позволили оценивать процессуальную активность адвоката c точки зрения ее эффективности и достаточности предпринятых усилий. Дисциплинарные органы адвокатской ассоциации вынуждены руководствоваться, по сути, принципом невмешательства в указанную сферу деятельности защитника, относя ее к стратегии и тактике защиты, которые адвокат определяет самостоятельно, будучи независимым советником по правовым вопросам.

В результате такой ситуации возникло противоречие между потребностями граждан в оказании им квалифицированной юридической помощи, в том числе и в части процессуально активности адвокатского познания, и уровнем научного знания относительно его оценки, отличающегося фрагментарностью, пробельностью и консерватизмом. Таким образом, законодатель уже определил возможность разработки стандартов адвокатской деятельности, однако до сих пор остается не исследованной наукой, что должен представлять из себя такой стандарт и насколько вообще возможно стандартизировать адвокатскую профессию.

Таким образом, в данной статье определено общее понятие правовой активности, выделен один из ее подвидов - процессуальная активность, а также доказана важность данного элемента в деятельности современного адвоката по любым видам судебного процесса, в том числе гражданского, уголовного административного и Т.П.

В целом, изложенные обстоятельства свидетельствуют об актуальности выбранной темы исследования, требуют научного анализа, разработки и формулирования предложений и рекомендаций.

$$
\text { *** }
$$

1. Лесникова А.М. Правовая активность и правовая культура / Лесникова А.М. / Приволжский научный вестник. 2014. №12-1 (40). URL: https://cyberleninka.ru/article/n/pravovaya-aktivnost-ipravovaya-kultura (дата обращения: 16.03.2021).

2. Воробьев С.М.,. Деформация правосознания личности в условиях дискредитации власти в российской Федерации / Воробьев С.М., Лещенко О.B / Вестн. Том. гос. ун-та. 2019. №442. URL: https://cyberleninka.ru/article/n/deformatsiya-pravosoznaniya-lichnosti-v-usloviyah-diskreditatsii-vlastiv-rossiyskoy-federatsii (дата обращения: 16.03.2021). 
3. Маслак Ю.А. Проблема деформации правосознания и пути ее преодоления / Маслак Ю.А / Огарёв-Online. 2019. №16 (57). URL: https://cyberleninka.ru/article/n/problema-deformatsiipravosoznaniya-i-puti-ee-preodoleniya (дата обращения: 16.03.2021).

4. Котова С.Г. Статус граждан в процессе судопроизводства как субъектов правовой активности печатная и электронная Тенденции развития науки и образования. Самара. 2020. №67. Ч.6, с. 43-46

5. Котова С.Г. Понятие и виды правовой активности граждан в процессе судопроизводства печатная и электронная Тенденции развития науки и образования. Самара. 2019. №54. Ч.5, с. 34-38.

6. Бащук С.Г. Роль ценностей в формировании правовой активности личности печатная Международный научно-практический журнал «Legea si Viata». - 2014. - №8/3, с. 7-10 (специализированное издание, Республика Молдова).

7. Беляева Г.С. К вопросу о роли правосознания гражданина и правоприменителя в механизме защиты прав и свобод граждан / Беляева Г.С., Антонова Ж.Д./ Economic Consultant. 2016. №3 (15). URL: https:/cyberleninka.ru/article/n/k-voprosu-o-roli-pravosoznaniya-grazhdanina-i-pravoprimenitelyav-mehanizme-zaschity-prav-i-svobod-grazhdan (дата обращения: 16.03.2021).

\section{Рахманкин Е.А., Козлова Е.Д. \\ Способы стабилизации оперативной обстановки в учреждениях уголовно- исполнительной системы}

Владимирский юридический институт ФСИН России

(Россия, Владимир)

doi: $10.18411 / \mathrm{j}-07-2021-98$

\section{Аннотация}

В данной статье раскрывается понятие оперативной обстановки, а также рассматриваются факторы, влияющие на ее состояние. Проводится исследование по выявлению наиболее эффективных способов стабилизации оперативной обстановки.

Ключевые слова: оперативная обстановка, исправительные учреждения, факторы, влияющие на оперативную обстановку, способы стабилизации.

\section{Abstract}

This article reveals the concept of the operational environment, and also considers the factors affecting its state. Research is being conducted to identify the most effective ways to stabilize the environment.

Keywords: operational environment, correctional institutions, factors influencing the operational environment, methods of stabilization.

Процесс управления исправительными учреждениями уголовно-исполнительной системы носит в большинстве своем ситуационный характер. Так, одним из немаловажных составляющих процесса принятия управленческих решений является состояние оперативной обстановки.

Оперативная обстановка - это системное понятие, которое может изменяться неожиданно под влиянием внешних и внутренних обстоятельств. Под оперативной обстановкой следует понимать совокупность внутренних и внешних условий, в которых осуществляется деятельность учреждений, исполняющих уголовные наказания в виде лишения свободы, имеющих качественные и количественные показатели, влияющие на криминогенную ситуацию в них, организацию и осуществление деятельности этих учреждений.[1]. Результатом реагирования на определенную оперативную обстановку является своевременное принятие решения, которое в дальнейшем может привести как к осложнению обстановки, так и к ее стабилизации. Состояние оперативной обстановки, ее изменение принято выявлять, опираясь на показатели информации (вид и место дислокации исправительного учреждения, лимит и фактическое наполнение учреждения; наличие либо отсутствие производства; криминологическая характеристика осужденных; количество осужденных склонных к 